\title{
Delayed Benefit From Aggressive Immunotherapy in Waxing and Waning Anti- IgLON5 Disease
}

Pauline Shambrook, MD, Adèle Hesters, MD, Clémence Marois, MD, Daniel Zemba, MD, Jérôme Servan, MD, Bertrand Gaymard, MD, PhD, Fernando Pico, MD, Cécile Delorme, MD, Catherine Lubetzki, MD, PhD, Isabelle Arnulf, MD, PhD, Dimitri Psimaras, MD, Jérôme Honnorat, MD, PhD, Ana Gales, MD, and Aurélie Méneret, MD, PhD

Neurol Neuroimmunol Neuroinflamm 2021;8:e1009. doi:10.1212/NXI.0000000000001009

Anti-IgLON5 disease is a rare disorder characterized by the variable association of movement disorders, sleep disturbances, cognitive impairment, bulbar symptoms, and respiratory dysfunction. ${ }^{1,2}$ Pathophysiology likely involves both autoimmune and neurodegenerative processes, and prognosis is considered to be poor. ${ }^{3,4}$ Here, we report a case with a waxing and waning course, who eventually responded well to aggressive and sustained immunotherapy.

\section{Case}

A 59-year-old woman presented with dysphagia, weight loss, and involuntary movements of the face and the upper limbs. Symptoms were stable for 6 months until she suddenly developed visual hallucinations, episodic nocturnal confusion, and severe insomnia. The diagnostic workup, including a generic autoantibodies panel, was negative. Blood gases were not performed. She was treated with clonazepam, which improved hallucinations and nocturnal behavior disorders. Three months later, she developed hypoxemia and hypercapnia as a consequence of central hypoventilation, discovered during an emergency department visit for confusion. Nocturnal noninvasive ventilation was started. Clinical examination showed diffuse myoclonus (predominant in the upper limbs, face, and tongue), dysarthria, mild parkinsonism and cerebellar signs limiting ambulation (video 1), and mild cognitive impairment (mini-mental state examination score 24 of 30 and frontal assessment battery score 17 of 18). Brain MRI, EEG, CSF, and EMG findings were unremarkable. Video polysomnography showed a major insomnia (total sleep time: 112 minutes/48 hours-recording), simple (4 limbs movements and pedaling) and complex (facial emotional expressions, chewing, and moaning) behaviors during undifferentiated NREM sleep (figure, video 1), absent REM sleep, and persistence of facio-lingual myoclonus during sleep. Video-oculographic recording showed reduced velocity of horizontal saccades without slowing of vertical saccades and an increased antisaccade error rate suggesting prefrontal involvement. Anti-IgLON5 antibodies were positive in serum (IgG1: 1/12,800 and IgG4: negative) and CSF (IgG1: $1 / 320$ and IgG4: $1 / 10$ ). Twelve months after disease onset, the patient was hospitalized in the intensive care unit for severe fluctuations of vigilance and hypercapnia.

\author{
Correspondence \\ Dr. Méneret \\ aurelie.meneret@aphp.fr
}

MORE ONLINE

- Video 

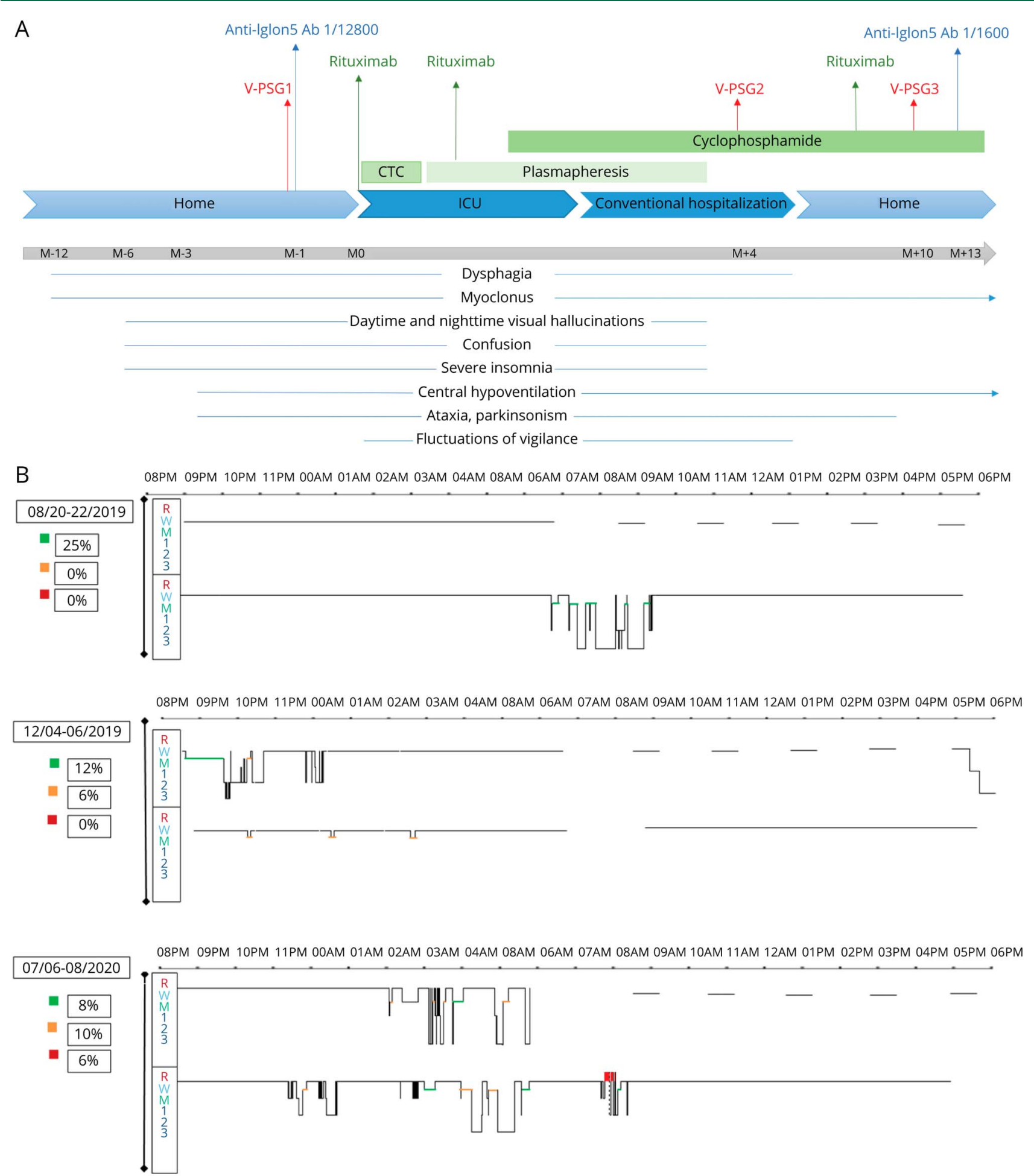

(A) Timeline showing disease symptom progression, paraclinical examinations, and treatments over time, expressed in months before and after treatment onset (MO). CTC = corticosteroids, V-PSG = video polysomnography, ICU = intensive care unit. (B) Sleep stages across nighttime and daytime during a consecutive 48-hour polysomnographical monitoring performed in the sleep laboratory, including a first night from 9 PM to 6:30 AM, followed by 5 multiple sleep latency tests and by a 24-hour bed rest procedure aimed at capturing the maximum time asleep per 24 hours. Lights off (LO) are presented in black horizontal bars. The same procedure was repeated before (M0), 4 months (M4), and 10 months (M10) after treatment onset. $X$ axis: time; $Y$ axis: $R=R E M ; W=$ awake; 1, 2, 3 = N1, N2, and N3 NREM sleep stages, M with 2 different stages = undifferentiated NREM sleep in green and subwakefulness in orange. The patient complained of severe insomnia at $\mathrm{M} 0$ and $\mathrm{M} 4$, but not at $\mathrm{M} 10$ and was always treated with noninvasive pressure ventilation and melatonin $(5 \mathrm{mg} / \mathrm{d}$ at $\mathrm{M} 0$ and $12 \mathrm{mg} / \mathrm{d}$ at M4 and M10). In addition, she was on low doses of clonazepam (0.3 $\mathrm{mg}$ at bedtime) for the first V-PSG and risperidone $1 \mathrm{mg} / \mathrm{d}$ for the following 2 . 
Immunotherapy was started, including high doses of corticosteroids for 5 days, followed by 15 plasma exchanges over 3 months, together with 4 courses of rituximab, and monthly cycles of cyclophosphamide for 1 year. Low doses of neuroleptics were added to control hallucinations and paranoid thoughts. The patient's condition stabilized, albeit with periods of improvement and worsening, making discharge from the hospital impossible for months. The video polysomnography performed 4 months after starting immunotherapy showed mostly an apparent sleep behavior (eyes closed and snoring) despite a wake (alpha rhythms) EEG, which we call "subwakefulness," intermingled with undifferentiated NREM sleep periods (totaling 127 minutes/48 hours) associated with simple and complex behaviors. Ten months after treatment onset, the patient's condition had considerably improved, with the disappearance of hallucinations and fluctuations of vigilance, cognitive improvement (MMSE score 29 of 30), weight gain, and improvement of walking perimeter to several kilometers, but she still had mild myoclonus and required nocturnal ventilation. In the video polysomnography, total sleep time increased (272 minutes/48 hours), movements and vocalizations with undifferentiated NREM sleep decreased, REM sleep resumed, but subwakefulness periods persisted (figure). At 13 months, anti-IgLON5 antibody levels had dropped in serum (IgG1: 1/1,600, CSF unavailable).

\section{Discussion}

In anti-IgLON5 disease, hypokinetic or hyperkinetic movement disorders are frequently described, including parkinsonism, myoclonus, myorhythmia, dystonia, chorea and tremor as well as ataxia, sometimes associated with supranuclear gaze palsy, making progressive supranuclear palsy and Whipple disease common differential diagnoses. ${ }^{1-3}$ However, the phenotype is usually milder at onset, as was the case in our patient, who initially only had dysphagia and myoclonus of the upper limbs and face. Diagnosis must therefore be suspected in adult patients presenting with subacute movement disorders, especially in association with sleep abnormalities, bulbar signs, or respiratory dysfunction. The diagnosis of autoimmune or paraneoplastic encephalopathy is usually evoked in those cases because various movement disorders are often part of the clinical phenotype. ${ }^{5}$ However, the correct diagnosis may be missed if not specifically looked for because anti-IgLON5 antibodies are not part of the first-line diagnostic panel in many centers. Polysomnography has major diagnostic value because anti-IgLON5 disease is associated with specific NREM and REM sleep disturbances, including movements and behaviors during sleep and undifferentiated NREM sleep. ${ }^{6}$ In addition, our patient also developed a subwakefulness stage containing a slow alpha EEG rhythm (reminiscent of wakefulness) combined with apparent sleep behavior concurrently with clinical improvement and reappearance of REM sleep, suggesting it could be a marker of neuronal functional recovery. ${ }^{7}$ Finally, as neuropathology suggests both autoimmune and neurodegenerative processes in anti-IgLON5 disease, immunotherapy is still debated. Our case demonstrated a good but delayed response to immunotherapy, after several months of waxing and waning, suggesting that early diagnosis as well as aggressive and sustained immunotherapy may be key in this disorder.

\section{Study Funding}

The authors report no targeted funding.

\section{Disclosure}

P. Shambrook, A. Hesters, C. Marois, D. Zemba, J. Servan, B. Gaymard, F. Pico, C. Lubetzki, I. Arnulf, D. Psimaras, J. Honnorat, and A. Gales report no disclosures relevant to the manuscript; A. Méneret received travel funding from Abbvie, Merz; C. Delorme received a research grant from the Federation internationale de l'automobile, travel funding from Merz, Boston Scientific, and Medtronic. Go to Neurology. org/NN for full disclosures.

\section{Publication History}

Received by Neurology: Neuroimmunology \& Neuroinflammation October 31, 2020. Accepted in final form March 10, 2021.

\section{Appendix Authors}

\begin{tabular}{|c|c|c|}
\hline Name & Location & Contribution \\
\hline $\begin{array}{l}\text { Pauline } \\
\text { Shambrook, } \\
\text { MD }\end{array}$ & $\begin{array}{l}\text { Department of Neurology, } \\
\text { Pitié-Salpêtrière Hospital, } \\
\text { AP-HP, Paris, France }\end{array}$ & $\begin{array}{l}\text { Major role in the acquisition } \\
\text { of data; analyzed the data; } \\
\text { drafted the article for } \\
\text { intellectual content }\end{array}$ \\
\hline $\begin{array}{l}\text { Adèle } \\
\text { Hesters, MD }\end{array}$ & $\begin{array}{l}\text { Department of Neurology, } \\
\text { Pitié-Salpêtrière Hospital, } \\
\text { AP-HP, Paris, France }\end{array}$ & $\begin{array}{l}\text { Major role in the acquisition } \\
\text { of data }\end{array}$ \\
\hline $\begin{array}{l}\text { Clémence } \\
\text { Marois, MD }\end{array}$ & $\begin{array}{l}\text { Department of Neurology, } \\
\text { Pitié-Salpêtrière Hospital, } \\
\text { AP-HP, Paris, France }\end{array}$ & $\begin{array}{l}\text { Major role in the acquisition } \\
\text { of data }\end{array}$ \\
\hline $\begin{array}{l}\text { Daniel } \\
\text { Zemba, MD }\end{array}$ & $\begin{array}{l}\text { Department of Neurology, } \\
\text { Versailles Hospital, Le } \\
\text { Chesnay, France; Yalgado } \\
\text { Ouédraogo Hospital, } \\
\text { Ouagadougou, Burkina } \\
\text { Faso }\end{array}$ & $\begin{array}{l}\text { Major role in the acquisition } \\
\text { of data }\end{array}$ \\
\hline $\begin{array}{l}\text { Jérôme } \\
\text { Servan, MD }\end{array}$ & $\begin{array}{l}\text { Department of Neurology, } \\
\text { Versailles Hospital, Le } \\
\text { Chesnay, France }\end{array}$ & $\begin{array}{l}\text { Major role in the acquisition } \\
\text { of data }\end{array}$ \\
\hline $\begin{array}{l}\text { Bertrand } \\
\text { Gaymard, } \\
\text { MD, PhD }\end{array}$ & $\begin{array}{l}\text { Department of } \\
\text { Neurophysiology, Pitié- } \\
\text { Salpêtrière Hospital, AP-HP, } \\
\text { Paris, France }\end{array}$ & $\begin{array}{l}\text { Major role in the acquisition } \\
\text { of data }\end{array}$ \\
\hline $\begin{array}{l}\text { Fernando } \\
\text { Pico, MD }\end{array}$ & $\begin{array}{l}\text { Department of Neurology, } \\
\text { Versailles Hospital, Le } \\
\text { Chesnay, France }\end{array}$ & $\begin{array}{l}\text { Major role in the acquisition } \\
\text { of data }\end{array}$ \\
\hline $\begin{array}{l}\text { Cécile } \\
\text { Delorme, } \\
\text { MD }\end{array}$ & $\begin{array}{l}\text { Department of Neurology, } \\
\text { Pitié-Salpêtrière Hospital, } \\
\text { AP-HP, Paris, France }\end{array}$ & $\begin{array}{l}\text { Major role in the acquisition } \\
\text { of data }\end{array}$ \\
\hline $\begin{array}{l}\text { Catherine } \\
\text { Lubetzki, } \\
\text { MD, PhD }\end{array}$ & $\begin{array}{l}\text { Department of Neurology, } \\
\text { Pitié-Salpêtrière Hospital, AP- } \\
\text { HP, Paris, France; Sorbonne } \\
\text { University, Paris, France }\end{array}$ & $\begin{array}{l}\text { Major role in the acquisition } \\
\text { of data }\end{array}$ \\
\hline
\end{tabular}


Appendix (continued)

\begin{tabular}{|c|c|c|}
\hline Name & Location & Contribution \\
\hline $\begin{array}{l}\text { Isabelle } \\
\text { Arnulf, MD, } \\
\text { PhD }\end{array}$ & $\begin{array}{l}\text { Sleep Disorder Unit, Pitié- } \\
\text { Salpêtrière Hospital, AP- } \\
\text { HP, Paris, France; Sorbonne } \\
\text { University, Paris, } \\
\text { France }\end{array}$ & $\begin{array}{l}\text { Interpreted the data; revised } \\
\text { the article for intellectual } \\
\text { content }\end{array}$ \\
\hline $\begin{array}{l}\text { Dimitri } \\
\text { Psimaras, } \\
\text { MD }\end{array}$ & $\begin{array}{l}\text { Service de Neurologie 2- } \\
\text { Mazarin, Groupe Hospitalier } \\
\text { Pitié-Salpêtrière et } \\
\text { Université Pierre et Marie } \\
\text { Curie-Paris 6, AP-HP; } \\
\text { Centre de Compétence des } \\
\text { Syndromes Neurologiques } \\
\text { Paranéoplasiques et } \\
\text { Encéphalites } \\
\text { Autoimmunes, Paris, } \\
\text { France }\end{array}$ & $\begin{array}{l}\text { Major role in the acquisition } \\
\text { of data }\end{array}$ \\
\hline $\begin{array}{l}\text { Jérôme } \\
\text { Honnorat, } \\
\text { MD, PhD }\end{array}$ & $\begin{array}{l}\text { French Reference Center } \\
\text { on Paraneoplastic } \\
\text { Neurological Syndromes } \\
\text { and Autoimmune } \\
\text { Encephalitis, Hospices Civils } \\
\text { de Lyon, Institut } \\
\text { NeuroMyoGene, INSERM } \\
\text { U1217/CNRS UMR5310, } \\
\text { Université de Lyon, } \\
\text { Université Claude Bernard } \\
\text { Lyon } 1\end{array}$ & $\begin{array}{l}\text { Major role in the acquisition } \\
\text { of data }\end{array}$ \\
\hline
\end{tabular}

Appendix (continued)

\begin{tabular}{lll}
\hline Name & Location & Contribution \\
\hline $\begin{array}{l}\text { Ana Gales, } \\
\text { MD }\end{array}$ & $\begin{array}{l}\text { Sleep Disorder Unit, Pitié- } \\
\text { Salpêtrière Hospital, AP-HP, } \\
\text { Paris, France }\end{array}$ & $\begin{array}{l}\text { Major role in the acquisition } \\
\text { of data; interpreted the data; } \\
\text { revised the article for } \\
\text { intellectual content }\end{array}$ \\
$\begin{array}{l}\text { Aurélie } \\
\text { Méneret, } \\
\text { MD, PhD }\end{array}$ & $\begin{array}{l}\text { Department of Neurology, } \\
\text { AP-HP, Paris, France; }\end{array}$ & $\begin{array}{l}\text { Design and conceptualized } \\
\text { study; major role in the } \\
\text { acquisition of data; interpreted } \\
\text { the data; revised the article for } \\
\text { intellectual content }\end{array}$ \\
\hline
\end{tabular}

\section{References}

1. Honorat JA, Komorowski L, Josephs KA, et al. IgLON5 antibody: neurological accompaniments and outcomes in 20 patients. Neurol Neuroimmunol Neuroinflamm. 2017;4(5):e385. doi: 10.1212/NXI.0000000000000385.

2. Nissen MS, Blaabjerg M. Anti-IgLON5 disease: a case with 11-year clinical course and review of the literature. Front Neurol. 2019;10:1056.

3. Sabater L, Gaig C, Gelpi E, et al. A novel non-rapid-eye movement and rapid-eye-movement parasomnia with sleep breathing disorder associated with antibodies to IgLON5: a case series, characterisation of the antigen, and post-mortem study. Lancet Neurol. 2014;13(6):575-586.

4. Cabezudo-García P, Mena-Vázquez N, Estivill Torrús G, Serrano-Castro P. Response to immunotherapy in anti-IgLON5 disease: a systematic review. Acta Neurol Scand. 2020;141(4):263-270.

5. Honnorat J, Joubert B. Movement disorders in autoimmune encephalitis and paraneoplastic neurological syndromes. Revue Neurologique. 2018;174(9):597-607.

6. Gaig C, Iranzo A, Cajochen C, et al. Characterization of the sleep disorder of antiIgLON5 disease. Sleep. 2019;42(9):zsz133.

7. Antelmi E, Ferri R, Iranzo A, et al. From state dissociation to status dissociatus. Sleep Med Rev. 2016 Aug;28:5-17. 


\title{
Neurology \\ Neuroimmunology \& Neuroinflammation
}

\author{
Delayed Benefit From Aggressive Immunotherapy in Waxing and Waning \\ Anti-IgLON5 Disease \\ Pauline Shambrook, Adèle Hesters, Clémence Marois, et al. \\ Neurol Neuroimmunol Neuroinflamm 2021;8; \\ DOI 10.1212/NXI.0000000000001009
}

This information is current as of May 13, 2021

\section{Updated Information \& Services}

References

Subspecialty Collections

Permissions \& Licensing

Reprints including high resolution figures, can be found at:

http://nn.neurology.org/content/8/4/e1009.full.html

This article cites 7 articles, 1 of which you can access for free at: http://nn.neurology.org/content/8/4/e1009.full.html\#\#ref-list-1

This article, along with others on similar topics, appears in the following collection(s):

All Movement Disorders

http://nn.neurology.org//cgi/collection/all_movement_disorders

All Sleep Disorders

http://nn.neurology.org//cgi/collection/all_sleep_disorders

Autoimmune diseases

http://nn.neurology.org//cgi/collection/autoimmune_diseases

Encephalitis

http://nn.neurology.org//cgi/collection/encephalitis

Information about reproducing this article in parts (figures,tables) or in its entirety can be found online at:

http://nn.neurology.org/misc/about.xhtml\#permissions

Information about ordering reprints can be found online:

http://nn.neurology.org/misc/addir.xhtml\#reprintsus

Neurol Neuroimmunol Neuroinflamm is an official journal of the American Academy of Neurology.

Published since April 2014, it is an open-access, online-only, continuous publication journal. Copyright

Copyright $\odot 2021$ The Author(s). Published by Wolters Kluwer Health, Inc. on behalf of the American

Academy of Neurology.. All rights reserved. Online ISSN: 2332-7812.

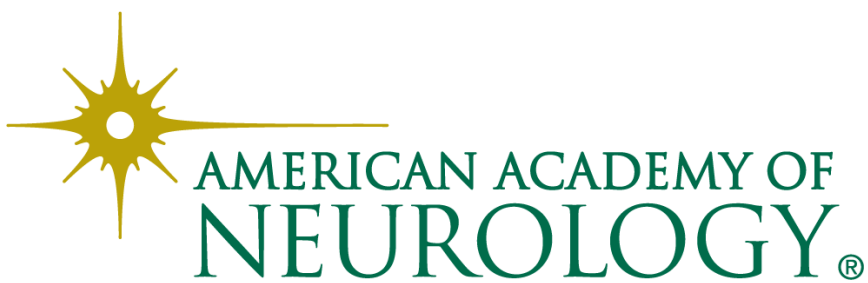

